Engineering History and Heritage Volume 167 Issue EH3

William Hazledine (1763-1840): pioneering iron founder

Pattison

\title{
William Hazledine (1763-1840): pioneering iron founder
}

Andrew Pattison MPhil, MB ChB, FRCS, MRCGP

Retired General Medical Practitioner and Local Historian, Shrewsbury, UK

William Hazledine (1763-1840) is a virtually forgotten figure in the history of engineering. He worked closely with Thomas Telford, and the list of their joint achievements in the UK is unmatched in the history of bridge engineering. These include the aqueducts of Chirk and Pontcysyllte; arch bridges at Bonar, Mythe, Tewkesbury and Craigellachie; lock gates and bridges for the Caledonian Canal and many smaller cast iron bridges; and, not least, the unprecedented suspension bridges at Conwy and Menai in North Wales. Hazledine's expertise also won him many other contracts, including the suspension bridge at Marlow in Buckinghamshire, and the ironwork for the first all-iron-framed multistorey building in the world, the Flax Mill at Ditherington in his home town of Shrewsbury. Recent research has begun to reveal his importance in the production of cast and wrought iron for these valued legacy structures. The paper highlights the outstanding quality of the iron that Hazledine made and the rigorous proof tests he undertook to verify the properties of the metal. These results will be of great interest to engineers today working on heritage castand wrought-iron structures, if only to learn of the high-quality results that were possible 200 years ago.

\section{Introduction}

Even in his home town of Shrewsbury, Shropshire, England, William Hazledine (1763-1840) is now virtually unknown. This is surprising, as one of his contemporaries described him as 'the first [foremost] practical man in Europe' (Anon, 1840), while another wrote, in relation to his achievements, that 'his biography would be worth compiling' (Hulbert, 1837, original emphasis). The chief reason for this general ignorance is 'that information about him is fragmentary and widely scattered, and [so] a biography of him is yet to be written' (Powell, in Skempton and Chrimes, 2002). A recent study of this material, allied with consideration of some of the works for which he was responsible, has led to a better understanding of his life and importance (Pattison, 2012) (Figure 1).

\section{Early life}

Perhaps because of inaccuracies in the entry in the Oxford Dictionary of National Biography (DNB) (Hughes, 2004), there has been confusion as to the spelling of 'Hazledine', and also William Hazledine's birthplace. Archival research indicates that by the eighteenth century the family always spelled its name 'Hazledine' and that William was not born in Waters Upton, as stated in the DNB, but in Shawbury, about $10 \mathrm{~km}$ north-east of Shrewsbury, on 6 April 1763 (Anon, 1763).

William Hazledine was born into a family of skilled craftsmen (Figure 2) His great-great grandfather (William I) was a miller at Waters Upton, $20 \mathrm{~km}$ north-east of Shrewsbury, by 1630 . $\mathrm{He}$ was also of sufficient standing to be appointed as a churchwarden (Anon, 1628ff). As well as millers, others of the next two generations were clock makers, servicing church clocks over a wide area (Elliott, 1979). His father, uncle and grandfather were all millwrights and forge carpenters, and after his grandfather's death, when William was aged 4, his family moved to the grandfather's former home at Moreton Forge, situated on the River Roden about $2 \mathrm{~km}$ north-east of Shawbury (Figure 3). After a basic education at the village charity school, William was apprenticed at age 15 to his uncle John, described as 'a man of considerable ability as a millwright and engineer' (Anon, 1840).

From this upbringing and training William had a solid grounding in millwrighting, which included technical drawing, carpentry, masonry and other building work, surveying and controlling the flow of water, and also the techniques of producing artefacts in iron and brass. As well as technical ability, his appearance and personality were also impressive (Shropshire Notes and Queries, 1901). Tall and broadshouldered, he was immensely strong. His facial features were heavy and rather forbidding, but he had a ready smile when pleased or amused. He was a man of few words, with a bluff manner and unpolished Shropshire accent, but he had a ready wit and was convivial in company. He had considerable ambition, but this was always tempered with caution in business affairs. All this enabled him to build up a successful business while many other people went to the wall in the turbulent political and economic circumstances of that time. He could be ruthless in business, but he was also sympathetic to the needs of his workers, unlike many of the employers of the day. Above all, he was a man of immense energy, throwing himself into a bewildering array of different branches of work. But this was balanced by attention to detail, which enabled him 
William Hazledine (1763-1840):

pioneering iron founder

Pattison

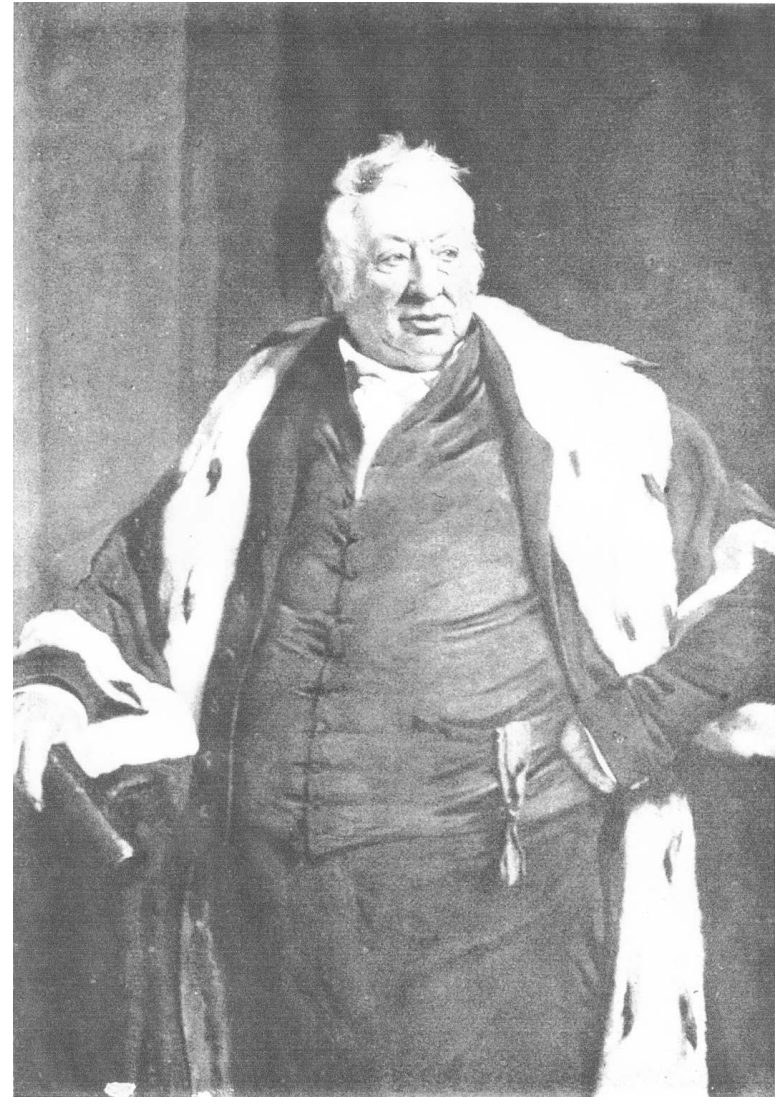

Figure 1. William Hazledine, as Mayor of Shrewsbury, 1836 (Anon, 1836)

to generally maintain a reputation for accuracy and promptitude in his business dealings.

Soon after William finished his apprenticeship in 1785 he set up his own business as a millwright and maker of French millstones in Shrewsbury. The business prospered, and he also entered the iron trade, going into partnership in a foundry (for the production of cast iron) in Shrewsbury around 1787, and leasing Pitchford Forge, about $11 \mathrm{~km}$ south of Shrewsbury, in 1789 for the production of wrought iron.

At the same time, William's older brother John (IV in the family tree), who had been apprenticed as a millwright to his father, became an iron founder and millwright in the Bridgnorth (south Shropshire) area. Around 1792 he set up his own foundry, and by 1801 was in partnership with his younger brother Robert (1768-1837) and his brother-in-law Thomas Davies. The youngest Hazledine brother, Thomas (1771-1842) also worked with the firm (Engineering Timelines, 2014). Hazledine \& Co developed a reputation for the production of agricultural machinery. From 1803 they also worked with Richard
Trevithick (1771-1833), in the production of high-pressure steam engines, including the famous Catch-me-who-can, and other castings, such as rails. The building of Catch-me-who-can was supervised by John Urpeth Rastrick (1780-1856), who became a partner in the firm around 1806. After John Hazledine's sudden death in 1810 , the firm continued to make engines for Trevithick and others, but disagreements over the construction of Chepstow Bridge (1815-1816) led to Rastrick leaving to set up on his own. The firm then became much less important, although Robert Hazledine and his son John (1796-1843) continued the business in a small way until the latter's death.

\section{Hazledine meets Thomas Telford}

In late 1786 Thomas Telford (1757-1834) arrived in Shrewsbury, initially to rebuild the castle for his mentor Sir William Pulteney (Rolt, 1979, p. 32). Rolt (1979, p. 66) suggests that Telford first met Hazledine at the Salopian Lodge of the Freemasons when the latter joined in June 1789. In all probability it was earlier than this, as a contemporary noted, 'Telford and Hazledine soon made each other's acquaintance, much to their mutual advantage. They were both thoroughly practical men who had risen from the ranks by the force of character and mental endowments' (Shropshire Notes and Queries, 1901). Another important new arrival to Shrewsbury about this time was the mason and master builder John Simpson (1755-1815), who moved in 1790 at the urgent request of architect George Steuart to oversee the rebuilding of St Chad's Church. The three men, Hazledine, Telford and Simpson, became lifelong friends as well as business associates, creating mutual confidence that would be important in many of Telford's major works (Pattison, 2007).

The first documented business relationship between Hazledine and Telford was in 1792, when Hazledine was commissioned as a drainage engineer by Sir William Pulteney to enable him to 'improve' lands in his Manor of Deytheur (Anon, 1788, 1792a). This was a considerable project, since Hazledine was required to provide a bond of $£ 700$ (upward of $£ 70000$ at today's prices) (Measuringworth, 2013). While doing this work Hazledine was also beginning to obtain contracts to build new agricultural mills, both wind- and water-powered, including their machinery. This is documented in a treatise that Telford wrote for the Board of Agriculture in 1798, entitled On Mills, which appears never to have been published (Telford, 1798; Telford and Burne, 1936). Presumably Telford got the commission to write it by way of Pulteney, but quite why he was considered expert enough to advise landowners and others on the current best practice in relation to mill machinery is obscure, as there is no record of his having been otherwise involved with mills. He must have been heavily reliant for his information on his friend Hazledine, a fact that he freely recognised, calling him 'a very ingenious practical 


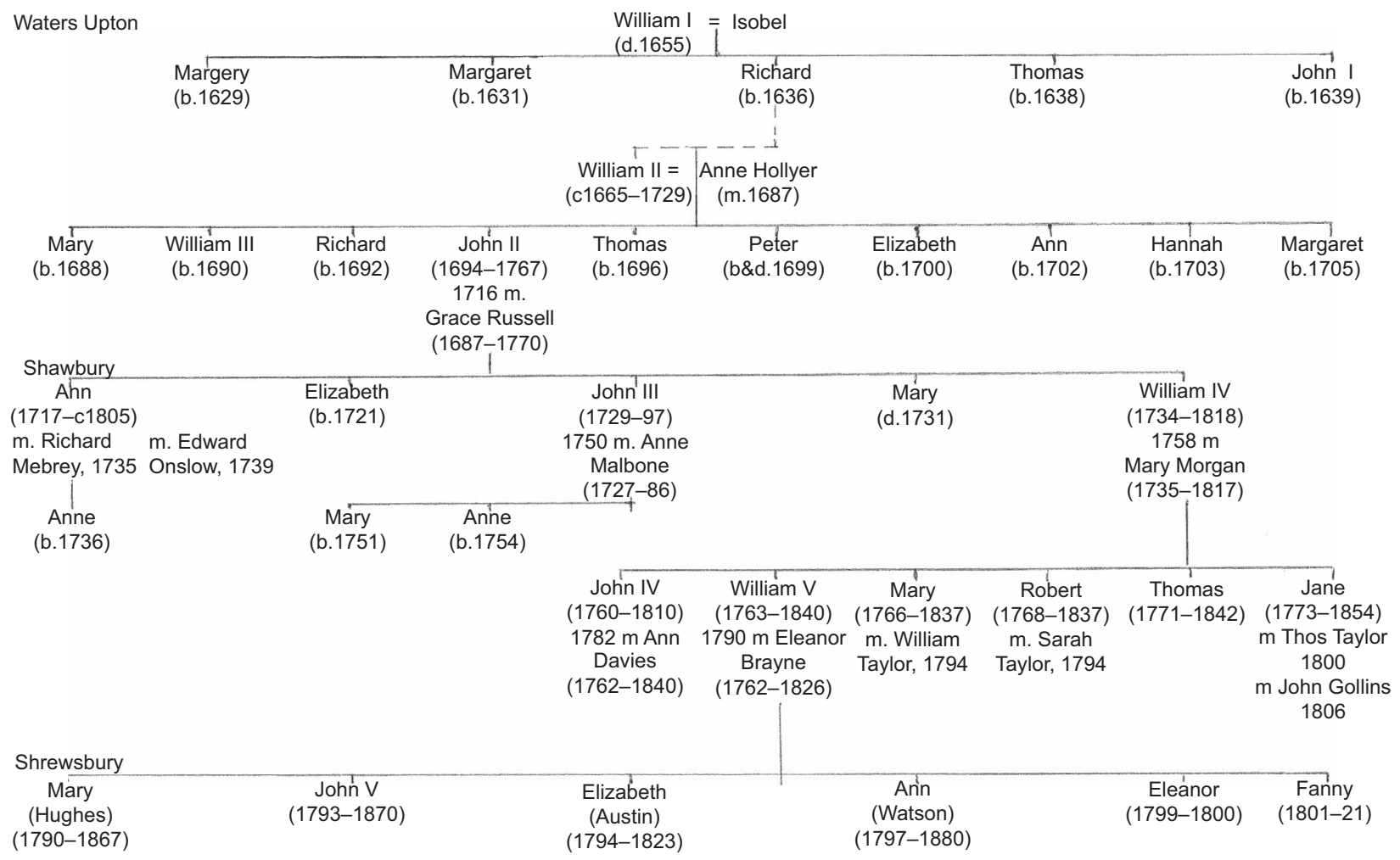

Figure 2. William Hazledine's family tree

millwright', in whose designs the reader could have confidence, as his 'mills were sanctioned by experience' (Telford, 1798). Telford and Hazledine must have had many conversations on the subject, and so the treatise gives a good insight into Hazledine's knowledge. Telford's report included a detailed history of mills of all types, and the theory and practice of making and using millstones. He also discussed waterwheels, including ground-breaking experimental work by John Smeaton (1724-92) on the efficiency of windmills and water wheels, tables of dimensions, water velocity and so on, and the latest thinking of William Strutt (1756-1830) the noted mill engineer and entrepreneur in the Derwent Valley north of Derby. The latter half of the treatise covered windmills, and included further reports of Smeaton's experiments. He also gave detailed information, with drawings and measurements, on both watermills and windmills designed and built by Hazledine (Figure 4). Assuming that Hazledine had a significant input into the treatise, this supports the view that he was not just a practical millwright, but was thoroughly versed in the history and theory of the subject as it was then understood. As examples of good practice, Telford described three watermills and four windmills that Hazledine had built before 1798, and stated that this was not an exhaustive list.

\section{Ditherington Flax Mill}

At this time Hazledine was also expanding his works for producing iron. From 1790 he began acquiring land in Coleham, a suburb of Shrewsbury just south of the River Severn, where he built his largest ironworks in stages (Anon, 1790, 1791, 1792b, 1793a). The foundry eventually came to occupy about $4350 \mathrm{~m}^{2}$, with a road frontage of around $93 \mathrm{~m}$, and several hundred men and women were employed there. In addition to the foundry itself, there was a large timber yard, saw mill, storage areas for ironwork, smith's shop, landing stage on the river, offices and other associated buildings.

Hazledine's most important commission during this period was the ironwork for Ditherington Flax Mill in Shrewsbury, designed by Charles Bage (1751-1822) and completed in 1797 (Minshull, 1803). This was the first completely iron-framed building in the world (Skempton and Johnson, 1962). The history and design of the building have now been well documented (Alan Baxter and Associates, 2006; Trinder, 1992), but Hazledine's importance in the project tends to be overlooked. The first mill to use cast-iron columns was Derby silk mill designed by William Strutt and completed in 1792 (Skempton and Johnson, 1962). Owing to anxiety about the strength of cast iron in tension, the beams at Derby were made 


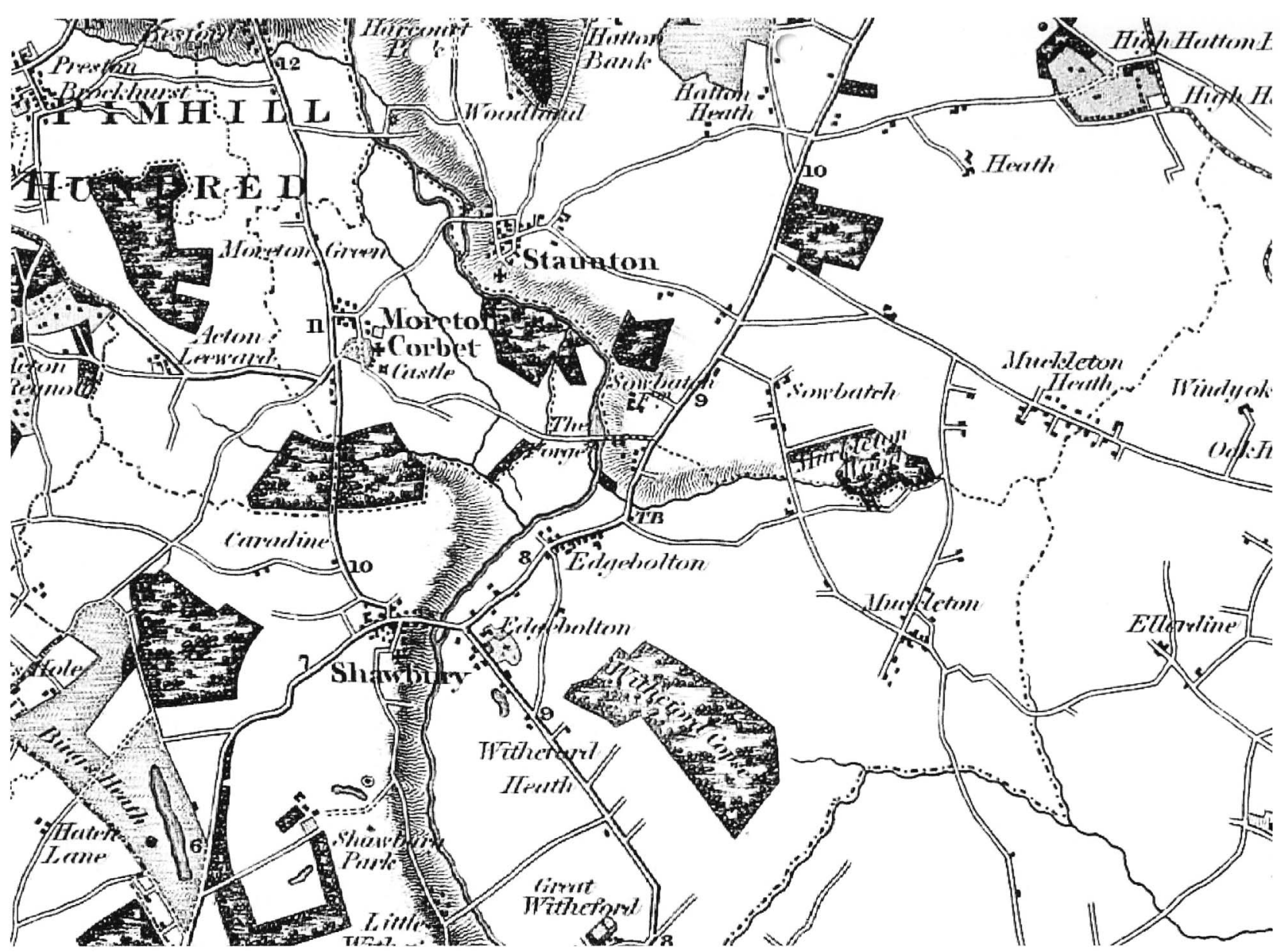

Figure 3. Environs of Moreton forge (Greenwood, 1827)

of timber coated with plaster to make them more fireproof. For Ditherington Mill, however, Charles Bage believed from both theoretical calculations and possibly also from experiment, that cast-iron beams could be strong enough to support the structure (Alan Baxter and Associates, 2006, Appendix F). At that time, however, iron production was still heavily dependent on the skill of the ironmaster, and so the fact that the mill has survived over 200 years of use (and misuse) is a testament to Hazledine's extraordinary skills. As part of a metallurgical assessment of the structure commissioned by the current owner, English Heritage, tests have been undertaken to establish the strength properties of Hazledine's iron. These gave the results shown in Table 1 .

The conclusions of the report were that, since 'much historic cast iron used in structures has been found to have a carbon equivalent value above $4 \cdot 3 \%$, many of the results [of these tests] show the tensile strength of the iron tested is higher than is typically found... The current recommendation for assessing historic cast-iron structures is to adopt a tensile strength of $123 \mathrm{~N} / \mathrm{mm}^{2}$ when no other data are available. This shows that the iron [in Hazledine's mill] is of above average quality' (Alan Baxter and Associates, 2006, section 5, p. 12).

Considering that this appears to have been Hazledine's first major ironwork contract, its size and complexity are astonishing. The original mill building has five storeys, and measures about $177 \times 39 \mathrm{ft}(54 \times 12 \mathrm{~m})$ (Alan Baxter and Associates, 2006, main report, p. 5ff). The external brick walls are load-bearing, and the internal structure is supported by a grid of columns, spaced at equal intervals, with 17 rows of three columns along the length of the building. Thus each floor has 51 columns, making a total of 204 columns in the first four storeys. In the attic storey, only the central columns from the fourth floor are extended up to roof level, which gives the roof its distinctive 'saw-tooth' appearance. The columns at each level support cast-iron beams between which brick jack-arches are built and which, in turn, support the flagstone floors. The brick jack-arches are supported laterally by 
Engineering History and Heritage

Volume 167 Issue EH3
William Hazledine (1763-1840):

pioneering iron founder

Pattison

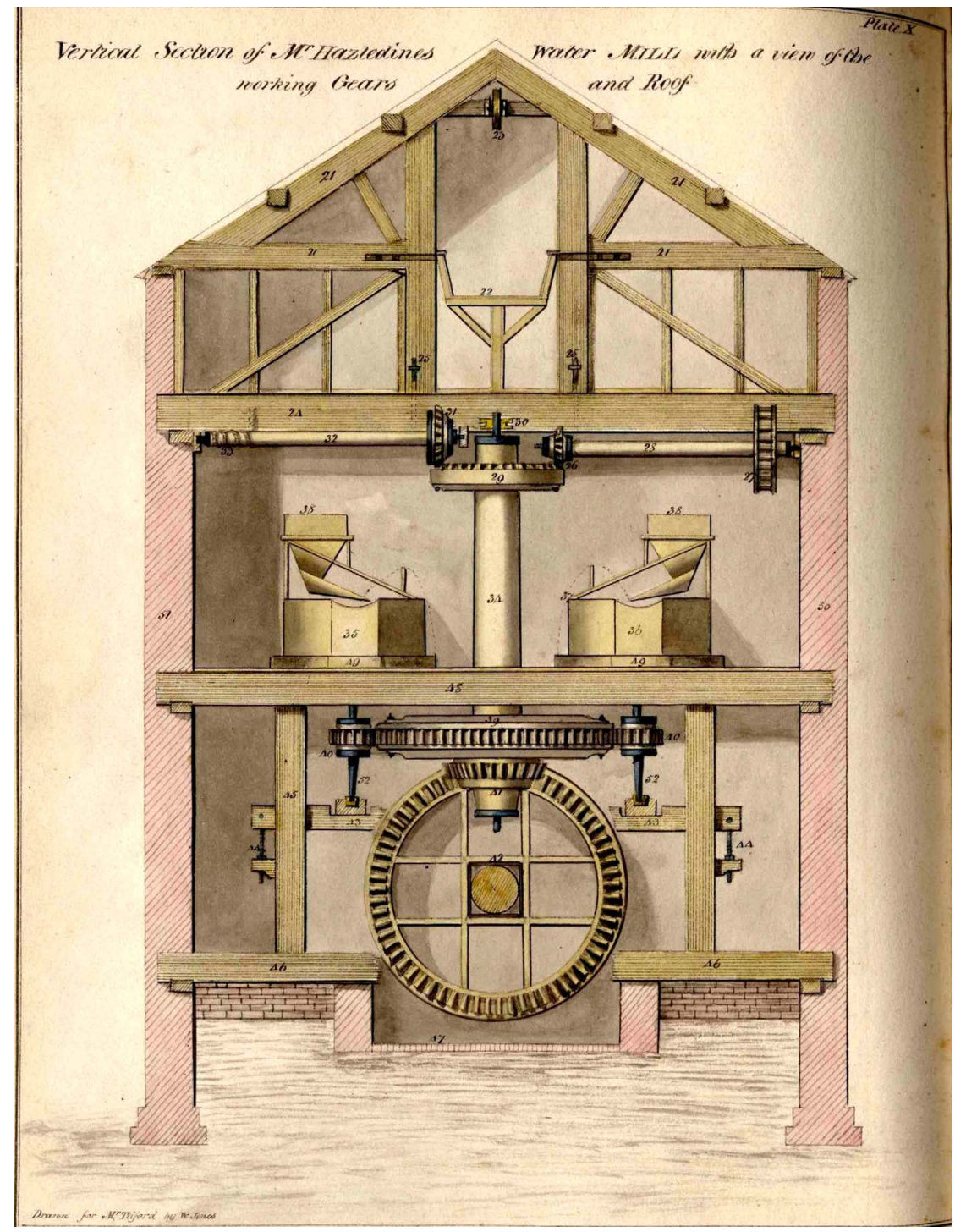

Figure 4. Vertical section of typical Hazledine water corn mill

(Telford, 1798, plate X, ICE)

\begin{tabular}{|c|c|c|c|c|c|c|c|}
\hline $\begin{array}{l}\text { Sample } \\
\text { origin }\end{array}$ & $\begin{array}{c}\text { Carbon equivalent } \\
\text { value: } \%\end{array}$ & $\begin{array}{l}\text { Tensile strength: } \\
\qquad \mathrm{N} / \mathrm{mm}^{2}\end{array}$ & Carbon: \% & Sulfur: \% & Silicon: \% & Manganese: \% & Phosphorus:\% \\
\hline Column & $3 \cdot 8$ & 230 & $2 \cdot 88$ & 0.063 & $2 \cdot 04$ & 0.63 & 0.73 \\
\hline Beam & $4 \cdot 1$ & 200 & $3 \cdot 18$ & 0.057 & 0.98 & 0.68 & $1 \cdot 77$ \\
\hline Beam & $4 \cdot 02$ & 215 & $3 \cdot 48$ & 0.039 & 0.95 & 0.69 & 0.67 \\
\hline Beam & $3 \cdot 86$ & 230 & $3 \cdot 29$ & 0.064 & $0 \cdot 87$ & 0.73 & $0 \cdot 84$ \\
\hline Beam & $4 \cdot 01$ & 215 & $3 \cdot 43$ & 0.041 & 0.82 & 0.76 & 0.82 \\
\hline
\end{tabular}




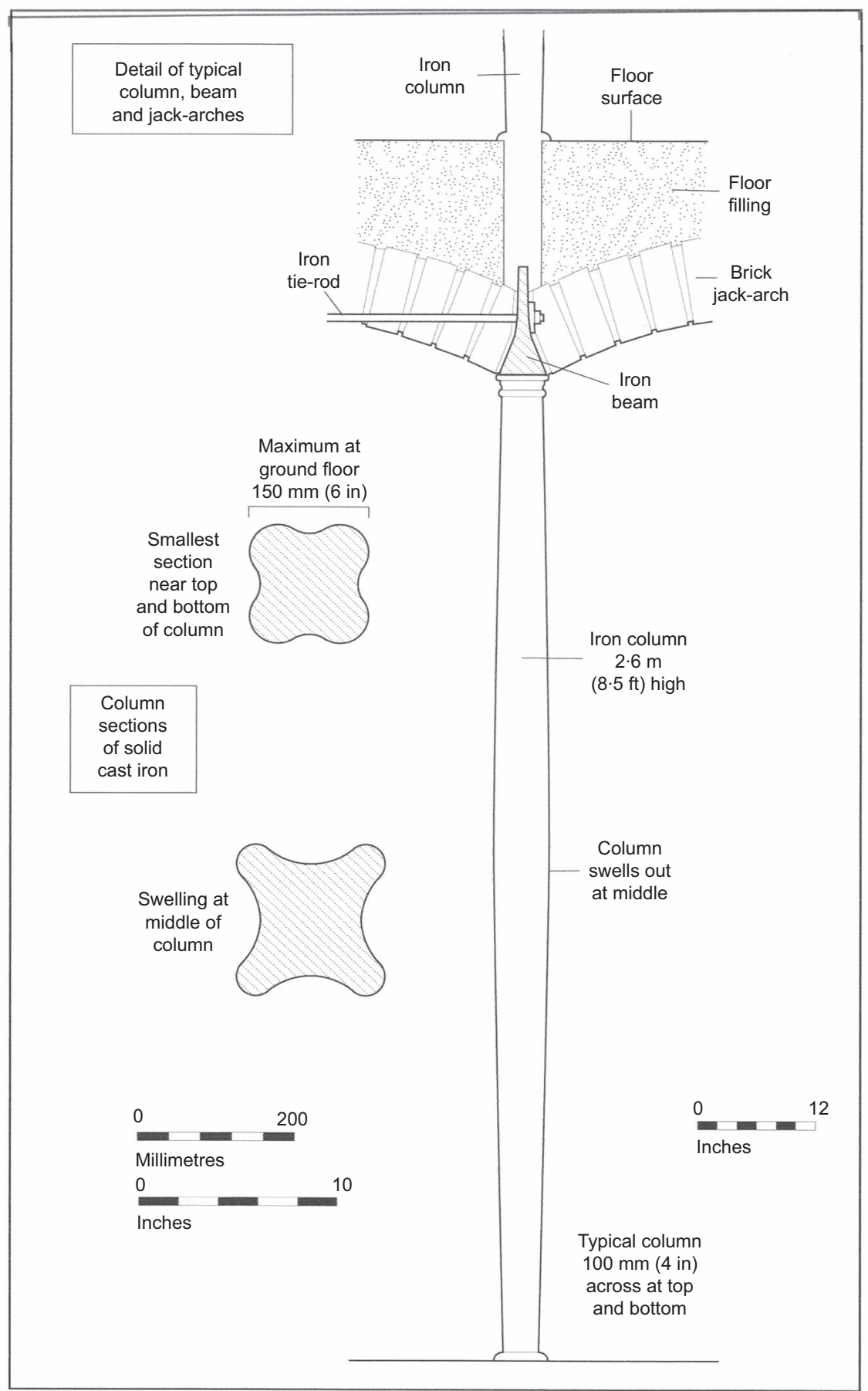

Figure 5. Details of the ironwork for Ditherington Flax Mill (English Heritage)

wrought-iron tie rods (Figures 5 and 6). The columns are of cruciform cross section and are thicker at mid-height than at the top and bottom to give maximum resistance to buckling. The columns at ground level are thicker ( $5 \mathrm{in} / 127 \mathrm{~mm}$ at mid-height) than those on the upper floor levels $(4.5 \mathrm{in} / 114 \mathrm{~mm})$, and the capitals of the central columns at the ground and fourth floor levels are cast with a large, rectangular void to accommodate drive shafts for machinery that ran the length of the building. 


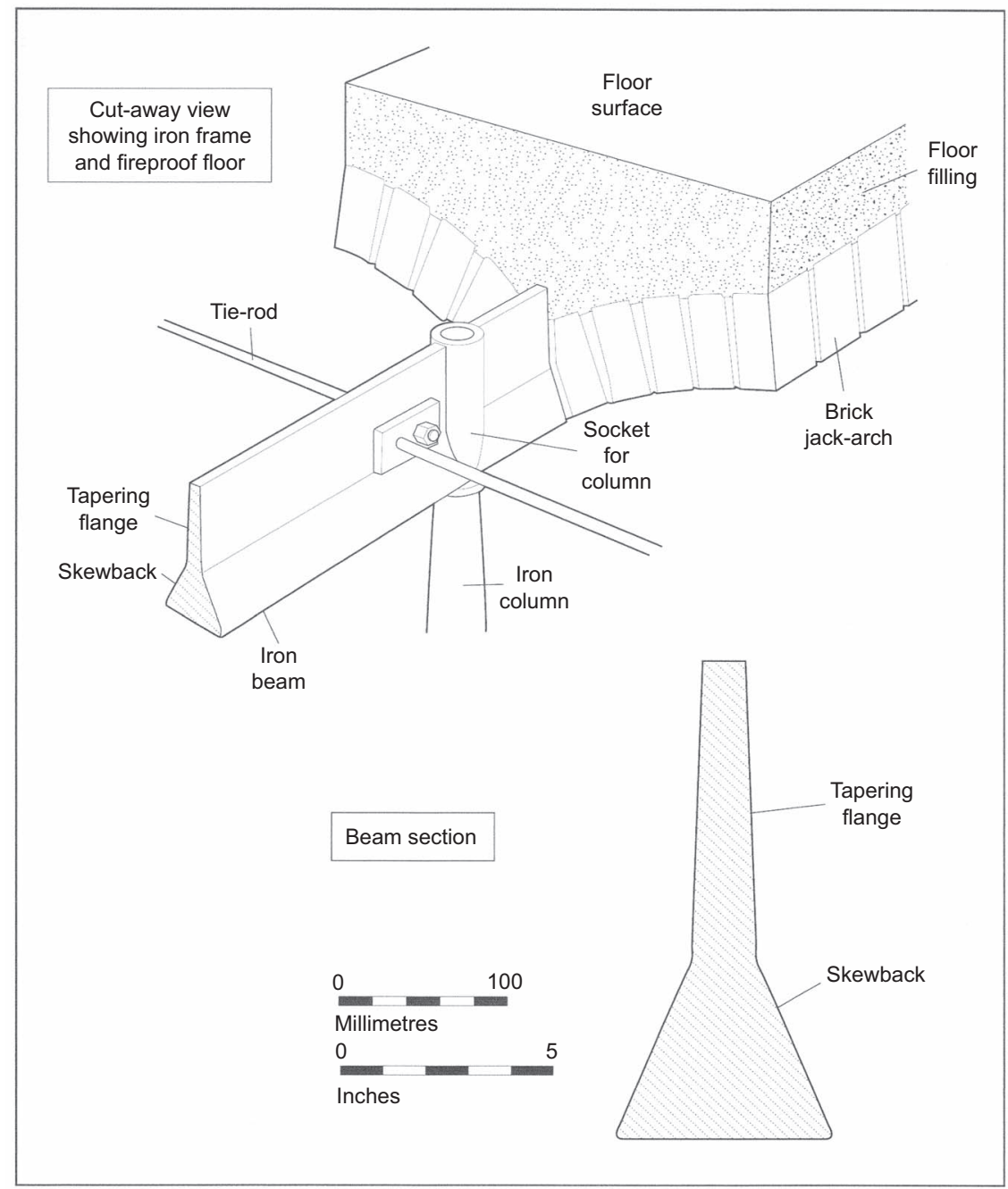

Figure 6. Details of the ironwork for Ditherington Flax Mill (English Heritage)

Each floor has 17 lines of beams, each cast in two lengths and bolted together in the centre of the building. There are thus 34 separate beams on each floor, a total of 136 in the whole building. The beams run continuously over the side columns, to which they are connected by way of cylindrical sockets in the beams and spigots in the tops of the columns. The beams are of an inverted-T cross section with a skewback, and have a slight hogback in the longitudinal direction, varying in depth from 7 in $(175 \mathrm{~mm})$ at the external walls to 10 in $(250 \mathrm{~mm})$ over the side columns and 11 in $(275 \mathrm{~mm})$ at their ends in the middle of the building where they join at the centre columns. At the wall end, the beam is shaped into a plate which sits between two timber pieces, and the whole is bolted together with wrought-iron rods. In summary, there were 204 columns cast in a number of different patterns, and 136 identical beams.
Assuming there was originally a window at either end of each bay, there would have been 136 cast-iron frame windows in the whole building, together with an unknown number of door frames. There are 19 separate roof sections (one for each bay, and one for one end); each of these is supported by cast-iron trusses. As well as the many cast-iron components, there must also have been many smaller wrought-iron pieces including door furniture, banisters, and other interior fittings. The whole complex structure needed to fit together like a giant Meccano set, and also to fit precisely with the brickwork. We do not know who the brickwork contractor was, but in all probability it was John Simpson who was, by then, in partnership with Hazledine, as he is credited with later work on the site, such as the Apprentice House and Clerk's House, both built before 1800 (Trinder, 1992). One can imagine the two friends 
spending many hours planning and puzzling how they could bring Charles Bage's scheme to reality!

\section{Aqueducts on the Ellesmere Canal}

Meanwhile Telford's career had taken a new course with his appointment, in 1793, by the Ellesmere Canal Company as 'General Agent, Surveyor, Engineer, Architect and Overlooker of the Works...to make drawings and submit them for the consideration and correction of Mr Jessop or their principal engineers' (Anon, 1793b). In recent years an attempt has been made to play down Telford's role in favour of the engineer in charge, William Jessop (Hadfield, 1969, 1993), but little consideration has been given to the input of others, including Hazledine. Their importance is hinted at by the words of Rowland Hunt in his oration at the opening of the Pontcysyllte Aqueduct, who said, 'We will mention, as concerned in the scientific and practical construction of the works, our General Agent Mr Telford; who, with the advice and judgment of our eminent and much respected Engineer, Mr Jessop, invented, and with unabating [sic] diligence carried the whole into execution... In such a history will be found deservedly mentioned, the names of $\mathrm{Mr}$ Hazledine, the spirited founder of the duct itself; of Mr Simpson, the accurate mason, who erected the pillars; the well-computed labours of Mr Davies, who constructed the mound and tunnels adjacent; and the careful and enlightened inspection of Mr Davison [sic], who overlooked the whole' (Anon, 1806). The 'Mr Davison' was Matthew Davidson (1755-1819) who had been a friend of Telford's since childhood, and had been persuaded to move from Scotland down to Shropshire in 1790 to oversee the building of Telford's first significant bridge at Montford, on the outskirts of Shrewsbury (Burton, 1999, p. 31). Telford then secured the appointment of Davidson as Inspector of Works for the Ellesmere Canal in February 1794 (Rolt, 1979, p. 58).

There was a great deal of debate and uncertainty as to the best way to build the aqueducts needed to cross the Dee and Ceiriog Rivers, as this would require a new approach to cope with the unprecedented height. While undertaking this work for the canal company, Telford was also using cast iron, a material that was new to him, for the building of Longdon-on-Tern aqueduct on the Shrewsbury Canal (1795) and Buildwas Bridge (1796) (Paxton, 2007). During the construction of the latter, Telford was in London helping to get a new Bill through Parliament to amend the line of the Ellesmere Canal, and he wrote to Matthew Davidson, 'The moment I was conjuring about a spring for the coffee house door this morning, who should make his appearance but the Arch Conjuror himself Merlin Hazledine. This was one of the most singular instances I have met with. We have been considering about the arch over the roadway...' (Ironbridge Gorge Museum Trust (IGMT), 1796). This is popularly taken to indicate that Telford had such a high regard for Hazledine's skill as a manipulator of iron that he likened him to the magician Merlin. In reality, in early 1796, Hazledine had not yet made anything in iron for Telford. In the author's view all Telford is saying is that Hazledine's unexpected appearance was that he seemed to appear out of nowhere like Merlin the magician. On the other hand, it does give a flavour of the sort of discussions that were taking place between the two men. The meaning of the expression 'the arch over the roadway' is obscure. Possibly it referred to Buildwas Bridge, which Telford designed with a Schaffenhausen suspension rib on either side, and hence the roadway might be said to go 'through' the arch (Paxton, 2007) (Figure 7).

Hazledine's first documented association with the Ellesmere Canal was in November 1799, when his tender for the ironwork for the Chirk aqueduct was accepted (Anon, 1799). Chirk aqueduct had a base made of 1 in $(2.5 \mathrm{~cm})$ thick cast-iron plates bolted together transversely. These plates tied together the side walls, which were made of hard burnt bricks sealed with waterproof Parkers Cement, and the outside faced with stone blocks (Figure 8). The ironwork was made at Coleham, transported the 8 miles $(12.9 \mathrm{~km})$ from Shrewsbury to the furthest arm of the Ellesmere Canal at Weston Lullingfields, which had opened in 1797, and then by way of the canal to Chirk.

\section{The Pontcysyllte aqueduct}

The Chirk aqueduct was completed in 1801, and its success encouraged the owners to commission Telford to design a second aqueduct at Pontcysyllte with a trough made entirely of cast iron. Hazledine's tender for this was accepted in March 1802 , according to the following minute,

Mr William Hazledine of Shrewsbury having proposed to execute the cast-iron work at Pontcysyllte Aqueduct on the following

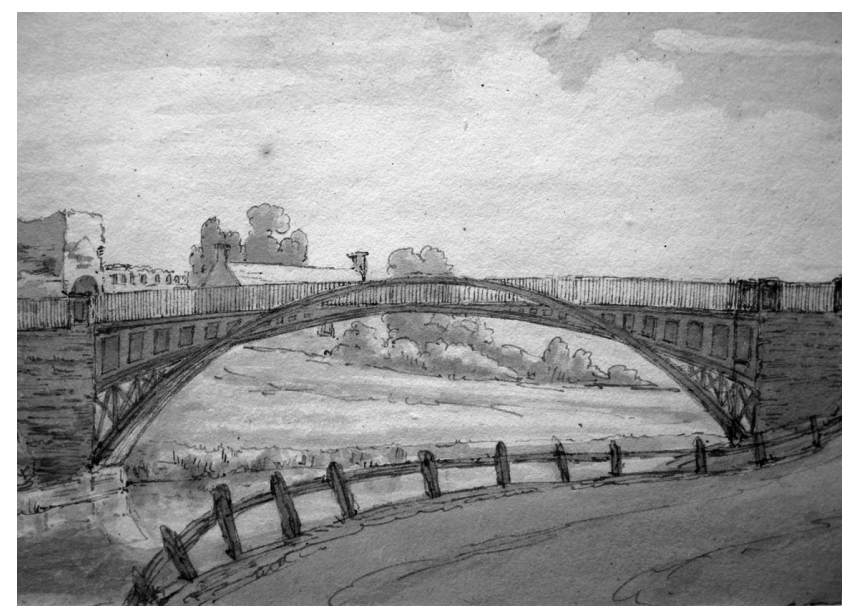

Figure 7. Buildwas Bridge, Shropshire. Note the pair of 'Schaffenhausen' suspension ribs (Ironbridge Gorge Museum Trust) 


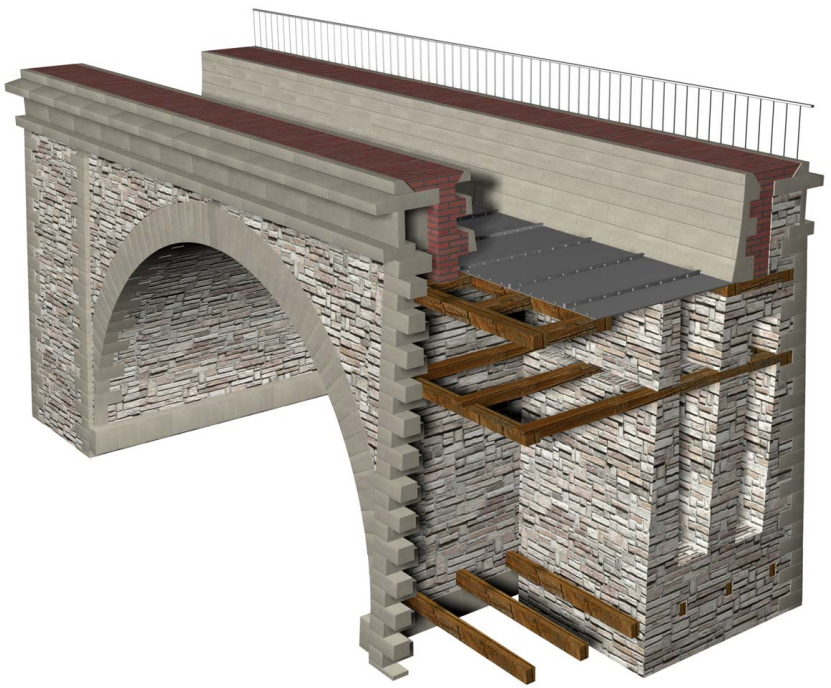

Figure 8. Still from three-dimensional model of Chirk aqueduct, showing cast-iron trough and masonry walls (ㄷ) Crown copyright: Royal Commission on the Ancient and Historic Monuments of Wales. See www.rcahmw.gov.uk/HI/ENG/Heritage+of+Wales/ World+Heritage+Wales/Pontcysyllte+Aqueduct+\%26+Canal (accessed 01/11/2013)

terms (viz.) the castings at $£ 11$ per ton, the wrought iron at $8 \mathrm{~d}$ per pound [i.e. $£ 7413 \mathrm{~s} 4 \mathrm{~d}$ per ton], and being allowed $£ 30$ for cast-iron keys to connect the plates of the aqueduct over and above the price of $£ 11$ per ton upon the whole weight and to perform the work in every respect according to the conditions and specifications now produced and signed by the said William Hazledine [author's emphasis] ... this Committee accept of the proposal... (Anon, 1802)

The emphasised phrase can be read two ways. Either the conditions and specifications had been produced by the committee (presumably by way of Telford) and then signed by Hazledine, or, perhaps more likely, Hazledine himself had produced the conditions and specifications. Either way, Hazledine had a significant input into the detailed design of the ironwork (Figures 9 and 10), which is as follows

The trough is constructed in 18 sections, each $44 \mathrm{ft}(13.4 \mathrm{~m})$ in length, and is $7 \mathrm{ft} 6$ in $(2 \cdot 29 \mathrm{~m})$ high and $11 \mathrm{ft} 10 \mathrm{in}(3.61 \mathrm{~m})$ wide. It is made up of $1 / 4$ in $(6.4 \mathrm{~mm})$ thick plates bolted together along the flanges... Each section of trough is designed to imitate a flat stone arch, the side plates shaped to imitate the voussoirs. Supporting each section are four ribs, cast in three sections and bolted together with connecting plates, the outermost ribs having infill plates which give the impression of a solid span. These ribs sit on cast-iron springing plates built into the stonework near the top of each pier. The trough is not directly attached to the ribs or the piers, but is instead prevented from moving laterally by a number of

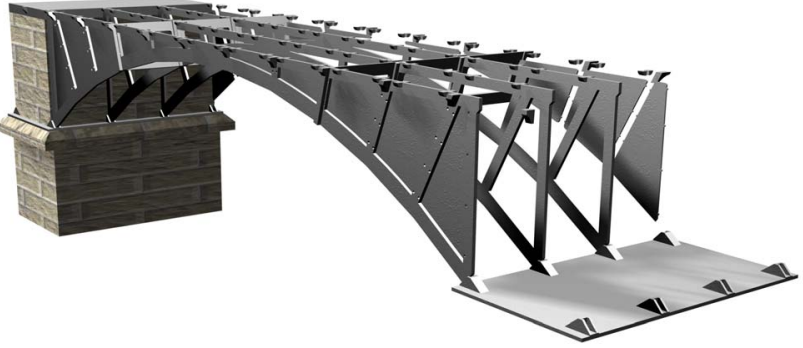

Pontcysyllte Aqueduct: NPRN 34410

View of a representative span with the trough and one pier removed to show the bracing and spports
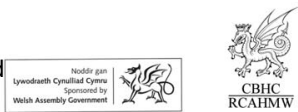

Figure 9. Pontcysyllte aqueduct, exploded view of the ironwork (c) Crown copyright: Royal Commission on the Ancient and Historic Monuments of Wales. See www.rcahmw.gov.uk/HI/ENG/ Heritage+of+Wales/World+Heritage+Wales/

Pontcysyllte+Aqueduct+\%26+Canal (accessed 01/11/2013)

brackets and lugs cast onto the underside of trough base plates and which straddle the top edges of the ribs (RCAHMW website).

(Figures 9 and 10)

The quantity of iron needed was staggering. The 19 piers, up to $126 \mathrm{ft}(38 \mathrm{~m})$ high, support 18 arches, each spanning $53 \mathrm{ft}$ $(16 \mathrm{~m})$ and consisting of four ribs each cast in three sections. This is a total of 216 castings. Similar calculations give a total of 216 voussoirs, 240 infill plates, and so on - literally thousands of major castings, before all the bolts, fixings and so

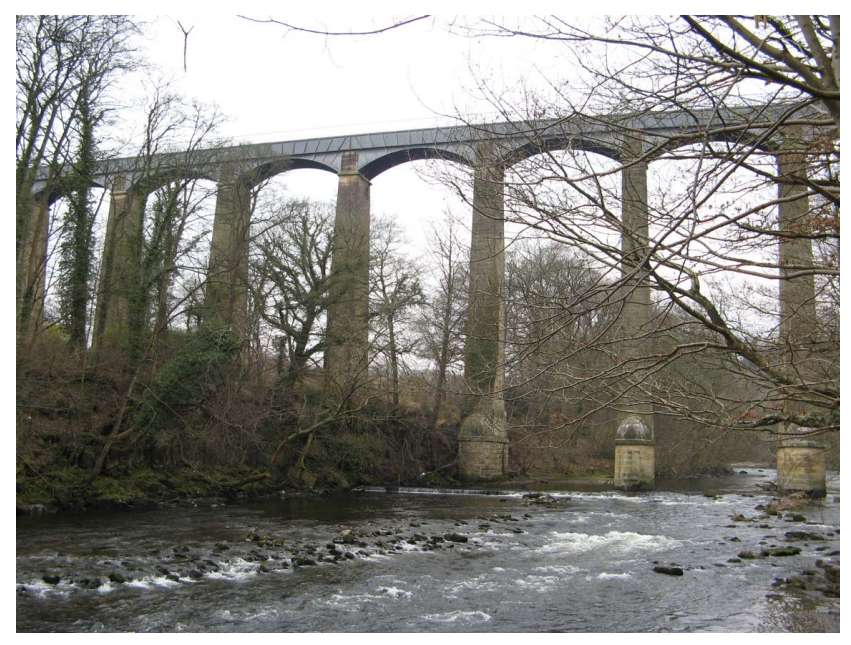

Figure 10. Pontcysyllte Aqueduct. Photograph by the author 
on are added. To do all this ironwork, Hazledine used his new works at Plas Kynaston. The Plas Kynaston foundry was built on the estate that he leased, and was about $1 / 3$ mile $(600 \mathrm{~m})$ from the Pontcysyllte canal basin. In 1803 it was proposed to build a 'railway' (tram-road) from the Pontcysyllte Basin to Ruabon Brook that passed near the foundry, but it took until November 1804 for the committee to organise Hazledine's contract to supply the castings (at $£ 11$ a ton) for the double railway (tram-road), and also laying down the tracks (Anon, 1804). In the meantime, all the ironwork from the new foundry would have to be taken to the aqueduct by horse and cart.

In 1805 Hazledine himself supervised the erection of the castiron trough of Pontcysyllte, which must have been both exhausting and frightening for men unaccustomed to working at heights up to $126 \mathrm{ft}(38 \mathrm{~m})$ with no safety gear. The concern of both Hazledine and Telford for the safety of their workmen is demonstrated by the fact that only one man lost his life in the erection of the aqueduct (Rolt, 1979, p. 73). Telford seems largely to have left Hazledine to his own devices as, by 1805 , Telford had moved to London and was also deeply involved in the Caledonian Canal, to which Matthew Davidson had also been transferred in 1804 (Burton, 1999, p. 77f; Engineering Timelines, 2013b). Indeed, if later correspondence is anything to go by, Telford seems to have had little input into the detail of the ironwork erection.

In 1818 Telford was asked to advise on the construction of similar aqueducts on the Glasgow and Edinburgh Union Canal, and he sent his assistant William Thomson to report on the construction of Pontcysyllte. Thomson described the dimensions of the ironwork in detail, and then explained how the trough was made watertight. He wrote

The jointing is done with very coarse flannel in the state it comes from the loom, cut into pieces to suit the flanges, and well covered with white lead of the normal consistency for jointing. And more or less of the pieces are needed in according [accordance] to the inequality of the joints which come together. The one also cut a little narrower than the flanges so as to leave a space on both sides to be caulked firmly up with good hemp rolled in tar, and hence well caulked and pitched over. I know of no simpler or cheaper method of jointing for cold water...I have never seen a piece of cast iron work more watertight than this aqueduct (ICE, 1818, T/EG $306)$.

Thomson then described how the ironwork was erected, writing,

The scaffolding and centering [sic] was done by leaving square holes in the piers two courses from the top, and running beams along from pier to pier in these holes, supporting each beam by diagonal braces under, and raising trestles over the beams (ICE, 1818).

This has been confirmed by recent detailed examination and recreated by computer animation (Pontcysyllte Aqueduct computer animation, 2013).

As a result of his work on the Ellesmere Canal, Hazledine became both much better known and well off. Leaving aside his share of the payment for the building of Chirk aqueduct, where he and Simpson were joint contractors, Table 2 summarises the remuneration he received:

We do not know what his expenses were, and the whole contract took ten years to complete, but his payment of at least $£ 1630000$ at today’s prices (Measuringworth, 2013), suggests that he made a good profit.

\section{Other canals and docks}

As already mentioned, after the Ellesmere Canal, much of Telford's focus turned to Scotland, in particular the Caledonian Canal. John Simpson acted as one of the main contractors, until his death in 1815 , for the western half of the

\begin{tabular}{ll}
\hline Work performed & Cost: $f$ / s / d \\
\hline Castings for swivel bridges and so on & $70 / 18 / 08$ \\
Ironwork for Chirk aqueduct & $1843 / 11 / 11$ \\
Rails, wagon wheels etc. for building embankment & $219 / 19 / 00$ \\
Ironwork for Pontcysyllte aqueduct & $17284 / 17 / 05$ \\
Iron rails, nails and so on for railway & $3643 / 10 / 02$ \\
Ironwork for 'water line' (canal to bring water supply from Bala Lake by way of Llangollen) & $98 / 07 / 10$ \\
Lime kiln building & $683 / 10 / 00$ \\
Boats, weights and repairs & $637 / 04 / 09$ \\
Total & $24481 / 19 / 10$
\end{tabular}

Table 2. Payments to William Hazledine for work on the Ellesmere Canal (Anon, 1805) 


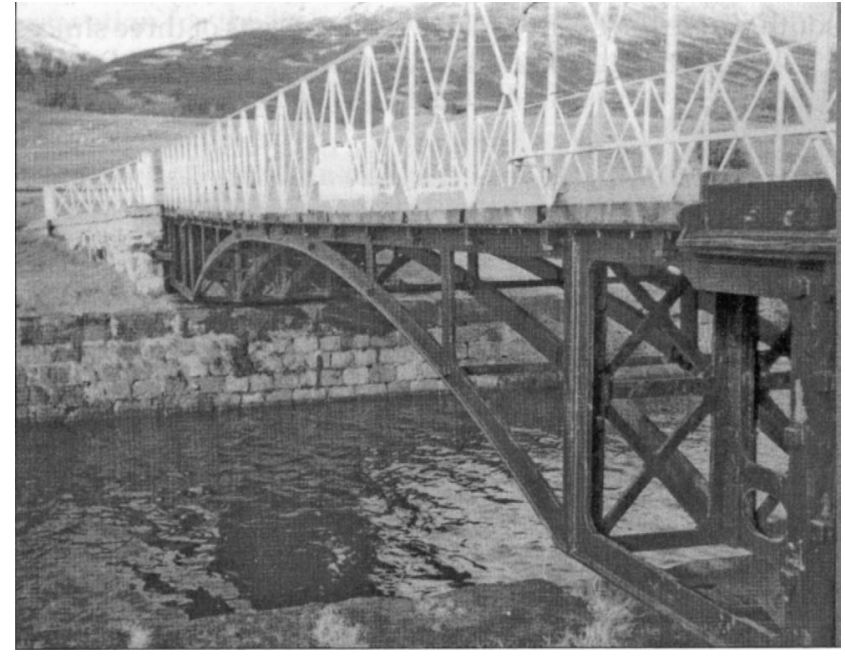

Figure 11. Moy turn bridge (Roland Paxton)

canal, for which Hazledine supplied the ironwork. This consisted of 14 pairs of cast-iron lock gates and an unknown number of turn-bridges (Telford and Rickman, 1838). Telford was forced to use cast iron for the lock gates because of the shortage of oak. Their size was unprecedented - the locks were $40 \mathrm{ft}(12 \cdot 2 \mathrm{~m})$ wide and $20 \mathrm{ft}(6 \cdot 1 \mathrm{~m})$ deep. The castings were made at Plas Kynaston, and first taken along the Ellesmere Canal to Chester, from where they were taken by sea to the western end of the Caledonian Canal. Sadly none of the original lock gates and only one of the turn-bridges, the one at Moy (Figure 11), survives (NN161826) (Paxton and Shipway, 2007, p. 160; Engineering Timelines, 2013a).

Hazledine also collaborated with Telford over the construction of the Göta Canal in Sweden (Burton, 2007; ICE, 1819, T/GC 208). A pair of lock gates similar to those used on the Caledonian Canal was cast at Calcutts (near Ironbridge, leased by Hazledine c.1817-1831), and then shipped over to Sweden. James Thomson, who had been an associate of Telford but was then working with Hazledine, travelled to Sweden to help establish a new iron foundry near the canal, where the remainder of the lock gates were fabricated using Hazledine's pattern. Hazledine also provided turn bridges for docks in both Liverpool (Princes and George's, 1820s) and London (Shadwell, 1831) (Taylor et al., 2009; Skempton, 1981).

\section{Small cast-iron bridges}

Despite living permanently away from Shropshire after 1803, Telford remained the County Surveyor until his death, although he delegated much of the work to his deputy Thomas Stanton (1782-1846) (Shrewsbury Local History, 2013). In 1811 Telford designed the first of a new genre of small prefabricated cast-iron bridges at Meole Brace (SJ

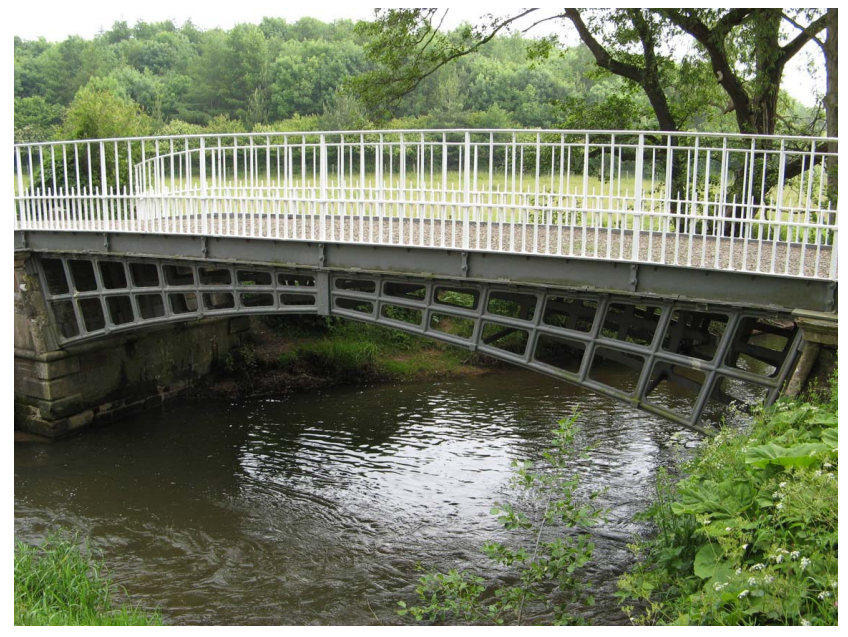

Figure 12. Cantlop Bridge, the author

491107) on the outskirts of Shrewsbury, using ironwork supplied by Hazledine's Coleham foundry. The ironwork consisted of four ribs, each cast in two halves, as mirror images. The ribs sprang from sloping stone abutments and consisted of a curved lower member and a straight upper member. Between the two was another member of a lesser curvature than the lower one, pierced by holes for cross members which joined the arches together. The three horizontals were joined by uprights reminiscent of the voussoirs of a stone bridge or the sections of the Pontcysyllte aqueduct. The castiron roadway was bolted onto the upper members of the arches, and so provided further stability for the bridge. Meole Bridge had a span of $55 \mathrm{ft}(16 \cdot 8 \mathrm{~m})$, and it was followed by Long Mill (1812, SJ 617155) with the span of $28 \mathrm{ft}(8 \cdot 5 \mathrm{~m})$, Cantlop (1813, SJ 517063) (Figure 12), with a span of $31 \mathrm{ft}(9 \cdot 5 \mathrm{~m})$ and Cound (1818, SJ 558057), which was identical to Meole (Blackwall, 1985; Hill, 1959). The only one that survives in situ, although not now load-bearing, is Cantlop.

\section{Large cast-iron bridges}

Concurrent with these bridges, Telford was engineering another new genre of large, light-weight, prefabricated, castiron bridges with a lattice spandrel arch, described by the poet Southey as 'something like a spider's web in the air' (Scotsites eBooks, 2011). These have been described as 'epoch-making' and were particularly suitable for remote locations with fastflowing rivers liable to flood (Paxton, 2007; Paxton and Shipway, 2007, pp. 211-213). The bridges of this type for which Hazledine provided the ironwork are - the Bonar Bridge, Sutherland (NH 609917), 1813; Craigellachie, Grampian (NJ 285452), 1814; the 'Waterloo' Bridge, Bettws-y-Coed, Gwynedd (SH 799557) (Figure 13), 1816; River Esk, Cumbria (NY 354649), 1820; Mythe, Tewkesbury, Glos (SO 889337), 1826; and Holt Fleet, Ombersley, Worcs (SO 824634), 1828. 
William Hazledine (1763-1840):

pioneering iron founder

Pattison

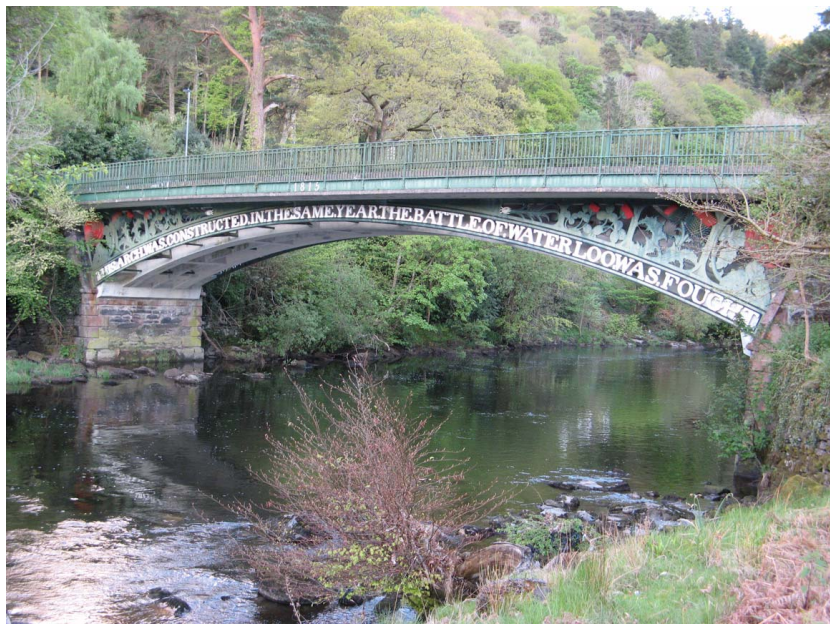

Figure 13. 'Waterloo Bridge', Bettws-y-Coed. Photograph by the author

Eaton Hall, near Aldford, Cheshire (SJ 418601), 1824, is of the same design, but Telford was not involved.

Like the smaller bridges, these were of a standard design, with spans of either $150 \mathrm{ft}(45.7 \mathrm{~m})$ or $105 \mathrm{ft}(32 \mathrm{~m})$ or multiples thereof. The exception was Mythe which has a span of $170 \mathrm{ft}$ $(51.8 \mathrm{~m})$. Bonar, Craigellachie, Waterloo, Esk and Eaton Hall were all cast at Plas Kynaston. The components were then taken to Chester by way of the Ellesmere Canal, before being shipped to a point as near as possible to their final destination. Meanwhile, Hazledine's team travelled to the sites, where they erected the bridges. Mythe and Holt Fleet were cast at either Coleham or Calcutt's, and transported down the River Severn. Apart from the risks inherent in transporting such large structures to often remote places, the contractors were also exposed to financial risk, as Telford insisted that the work should be done for a 'closed' (i.e. fixed) sum. Telford needed all his powers of persuasion to encourage his friends Hazledine and Simpson (who constructed the masonry and approach roads) to undertake this work. Indeed, Telford reported that Hazledine was so 'miserable' with the contract for Bonar Bridge he would gladly have relinquished it (Gibb, 1935, pp. 155-156).

A happier example of Hazledine's work with Telford is provided by Mythe Bridge, which Telford called 'the most handsomest [sic] bridge which has been built under my direction' (Telford and Rickman, 1838) (Figure 14). Telford reluctantly became involved with the bridge after the work ran into serious problems with the foundations of the piers for a proposed bridge. He recommended that the design of three small iron arches should be abandoned and replaced with a

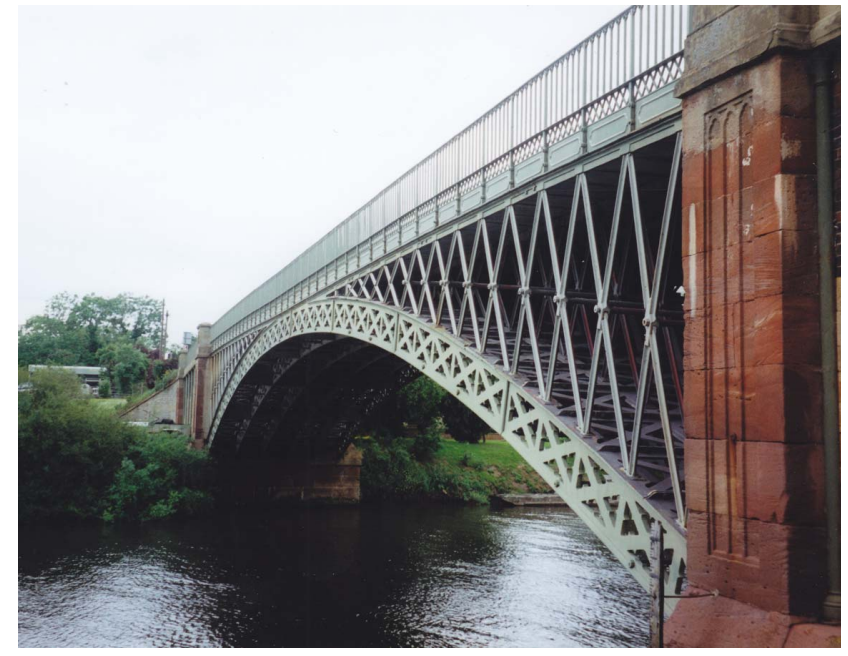

Figure 14. Mythe Bridge. Photograph by the author

single iron arch. Before he wrote his report he consulted with Hazledine, and so was able to state confidently that

although the quantity of iron required by the present plan is greater than by the former, yet, as Mr. Hazledine has at his works some of the apparatus used in the three similar bridges he has constructed for me [actually four], and his works being adapted and his workmen accustomed to the management of all the parts, he will execute this proposed plan of one arch of $170 \mathrm{ft}$ span for the same sum as his former proposal contained, that is to say, $£ 4,500$

(Mackenzie, 1838, p. 5).

After 30-odd years of friendship and collaboration Telford knew that his friend would not let him down.

Only Eaton Hall Bridge remains in use today as originally built, since it is used by light estate traffic only. Bonar and Esk have been replaced; Waterloo, Mythe and Holt Fleet are still in daily use by heavy traffic, but have been strengthened. Craigellachie is now a footbridge, but it had remained in full use until 1963 when it had to be dismantled above arch level due to some of the components working loose. As much of the ironwork as possible was retained, and the rest was replaced with identical parts in steel (Lowson, 1967a, 1967b). This provided an opportunity to understand the bridge's construction, the complexity of just part of which is illustrated in Figure 15.

A metallurgical analysis of the castings at Craigellachie Bridge was undertaken, the results of which are detailed in Table 3. The table compares these with the average metallurgical properties of the ironwork at the Ditherington Flax Mill. Even making allowances for the small number of samples and 


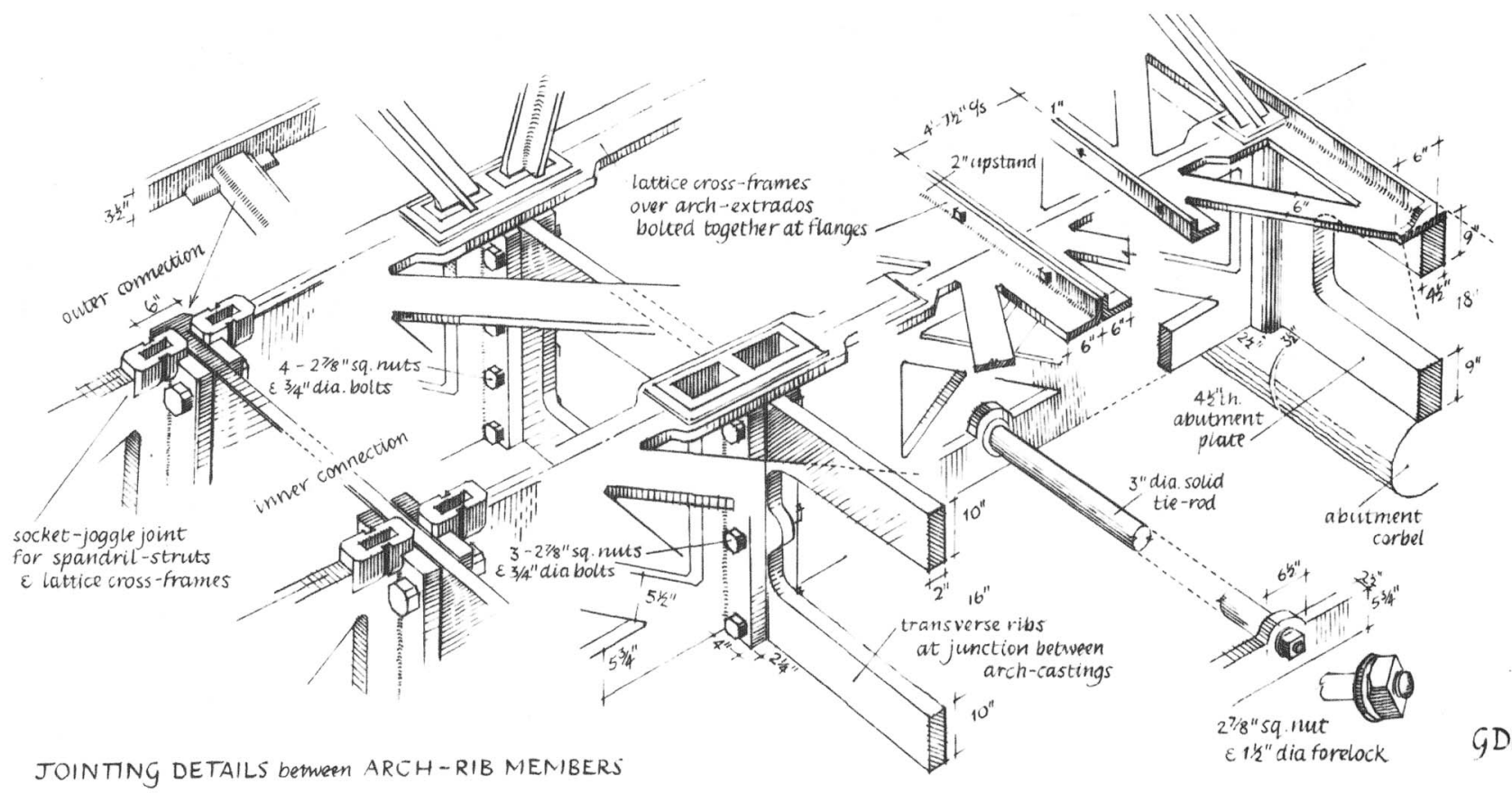

Figure 15. Details of joints used to construct Craigellachie Bridge (Royal Commission for the Ancient and Historic Monuments of Scotland, 2011)

possibility of changes in analytical methods between 1963 and 2006, the results show a greater purity of iron, with less sulfur and phosphorus, and an increase in content of beneficial manganese. In 1963 it was stated that the metal bore some of the characteristics of 'primitive steel', but it was cast iron of the highest quality (Lowson, 1967b, p. 289). In summary, Lowson, the engineer in charge of the reconstruction project, stated that, 'it did not seem possible that this [design] could have worked at all, but it did!' (Lowson, 1967b, p. 288).

Hazledine also provided the ironwork for two other large, castiron, arch bridges not designed by Telford. These were both

\begin{tabular}{lcc}
\hline Element & $\begin{array}{c}\text { Ditherington Flax Mill } \\
\text { beams (average): \% }\end{array}$ & $\begin{array}{c}\text { Craigellachie } \\
\text { Bridge: \% }\end{array}$ \\
\hline Total carbon & 3.35 & 3.61 \\
Silicon & 0.91 & 0.98 \\
Manganese & 0.40 & 0.72 \\
Sulfur & 0.19 & 0.05 \\
Phosphorus & 1.02 & 0.62
\end{tabular}

Table 3. Comparison of the metallurgical analysis of beams at Ditherington Flax Mill (1797) and Craigellachie Bridge (1814) (Alan Baxter and Associates, 2006, Appendix H; Lowson, 1967a, p. 26) founded at Calcutts and opened in 1827. Laira Bridge, near Plymouth (TA 044882), was designed by J. M. Rendel, with five arches and a total span of $452 \mathrm{ft}(137.8 \mathrm{~m})$, and Cleveland Bridge, Bath (SO 753657) was designed by Henry Goodridge and had a span of $110 \mathrm{ft}(33.9 \mathrm{~m})$. The former was replaced in 1962 , but the latter is still in use, although much strengthened (Dodds et al., 1995; Welch, 1966).

\section{Suspension bridges}

Perhaps the most celebrated structures on which Telford and Hazledine worked together are the Menai (SH 556714, 1826) and Conwy (SH 785776, 1826) suspension bridges in north Wales. Their scale has been accurately described as 'unprecedented' (Paxton, 1980, p. 103). Telford initially planned to use suspension chains formed from 0.5 in $(12.5 \mathrm{~mm})$ square bars welded together in segments. But before the ironwork contract was awarded to William Hazledine in July 1821, the design was totally changed to an improved design that had been pioneered by Captain Samuel Brown (1776-1852). He used long eye-bar chains in single lines (Paxton, 1980, pp. 94, 102). Telford's design consisted of:

Sixteen eye-bar chains, with each half of the deck being suspended at each side by two pairs of four vertically arranged chains. Each chain comprised five parallel flat-plate eye bars measuring about $9 \mathrm{ft} 1$ inch $(2.78 \mathrm{~m})$ between the centres of the eyes [the whole bar 


\begin{tabular}{|c|c|c|c|c|c|c|}
\hline & No. tested & $\begin{array}{l}\text { Rejected - visual } \\
\text { imperfections }\end{array}$ & $\begin{array}{l}\text { Cracked } \\
\text { under test }\end{array}$ & $\begin{array}{c}\text { Broke in two } \\
\text { under test }\end{array}$ & $\begin{array}{l}\text { No. sent } \\
\text { to site }\end{array}$ & $\%$ rejected \\
\hline $4^{\prime} \times 1^{\prime}$ bars for chains in tunnels etc. & 5032 & 60 & 0 & 0 & 4972 & $1 \cdot 2$ \\
\hline Connectors for ditto & 6238 & 175 & 0 & 0 & 6063 & $2 \cdot 81$ \\
\hline $31^{1} 4^{\prime} \times 1^{\prime}$ main chain bars & 10476 & 249 & 100 & 47 & 10080 & $3 \cdot 78$ \\
\hline Connectors for ditto & 13903 & 1438 & 225 & 90 & 12150 & $12 \cdot 61$ \\
\hline Total & 35649 & 1922 & 325 & 137 & 33265 & $6 \cdot 69$ \\
\hline
\end{tabular}

Table 4. Results of tests on ironwork for Menai and Conwy Bridges

(Provis, 1828, Appendix 3, p. 87)

was about $9 \mathrm{ft} 6$ inches $(2.9 \mathrm{~m})$ in length], with a cross section of $31 / 4$ by 1 inch $(83 \times 25 \mathrm{~mm})$. These were joined to the next group of eye bars by six short connecting plates, to which the hangers were attached. Single pins 3 inches in diameter and 16 inches long $(75 \mathrm{~mm} \times 406 \mathrm{~mm}$ ) passed through all eleven plies of iron at each connection (Day, 2007, p. 28).

One wonders if such a major change in specification resulted from discussions with Hazledine.

This work presented Hazledine with probably his greatest challenge. For Menai alone the 16 main chains, each $1710 \mathrm{ft}$ $(521 \mathrm{~m})$ long, consisted of 14960 eye-bars, around 16000 connecting plates, and 6000 screw-pins (Paxton, 1980). The chains needed a saddle at each end to allow them to pass over the masonry towers, and then had to be firmly anchored into rock. The saddles consisted of cast-iron rollers with brass bearings, designed to allow for expansion and contraction of the chains with changes in temperature. The chains were anchored by being attached to cast-iron plates, which were then screwed into the bedrock by means of wrought-iron bolts $9 \mathrm{ft} 6$ in $(2.9 \mathrm{~m})$ long. Work began on the wrought ironwork at Upton Forge (which Hazledine leased from 1800 to 1840) soon after the contract was signed, but it quickly became clear that to make all the pieces to the required tolerances would require a completely novel approach. Telford dispatched John Provis, the brother of resident engineer William, to Shrewsbury to supervise the testing of all the ironwork. To achieve this Telford (presumably with Hazledine) designed and built a 'proving machine', which took from January to June 1822 (Provis, 1828, p. 33ff). This machine was installed at Hazledine's headquarters in Shrewsbury, to which all the ironwork was brought from Upton by way of the Shrewsbury Canal. After testing, it was sent overland to Weston Wharf, then by way of the Ellesmere Canal to Chester, and finally by sea to Menai; the first consignment of bars for the main chains was delivered to Menai by October 1822 (Provis, 1828).

Another challenge that had to be overcome was forming the eyes in the eye-bars. Doing this under the hammer could result in irregular eyes with weaknesses where the metal had been worked, so it was decided to drill the eyes once the metal was cold using another specially designed machine. This work necessitated the installation of a new, more powerful, steam engine which, as well as punching the eyes of both main-chain plates and links, was also able to turn the rollers for the saddles which each weighed $9 \mathrm{cwt}(457 \mathrm{~kg})$, and cut screw-pins.

The introduction of these innovations took time, but the last links for the two bridges finally left the forge in March 1825 (ICE, 1825, T/EG 125). John Provis kept a meticulous record of all the tests he performed (Table 4). This is probably the first project for which the materials had been so extensively tested and, considering that the iron was forged using 'old' technology, the production of over 35000 items with a rejection rate of less than $7 \%$ speaks volumes for the skill of all those involved.

Hazledine was paid $£ 53050$ for his work on Menai and $£ 9345$ for Conwy, a total of $£ 62395$ (over $£ 4 \mathrm{~m}$ at today’s prices (Measuring Worth website)).

The only other suspension bridge with ironwork by Hazledine is at Marlow in Buckinghamshire (SU 851860). The engineer was William Tierney Clark (1783-1852), with whom Hazledine had a prolonged disagreement about the dimensions of the ironwork (Pattison, 2012, p. 166 ff). Hazledine insisted on getting his way, despite delaying the project by nearly two years, but hindsight proved him right, as the bridge needed no major repairs until the 1960s. This contrasts with the fate of Clark's other major suspension bridge in England, across the River Thames at Hammersmith in west London, which survived just 60 years before it had to be replaced.

By the 1960s the anchorages for the chains of Marlow Bridge were giving serious cause for concern, and it was felt the bridge needed replacement. An initial plan to demolish it and build a modern replacement produced a storm of protest in the town, and it was decided to dismantle the bridge and rebuild it to exactly the same design, but using steel instead of wrought iron. When the wrought iron came to be dismantled, much of it was still safe and serviceable, a tribute to the original workmanship. 


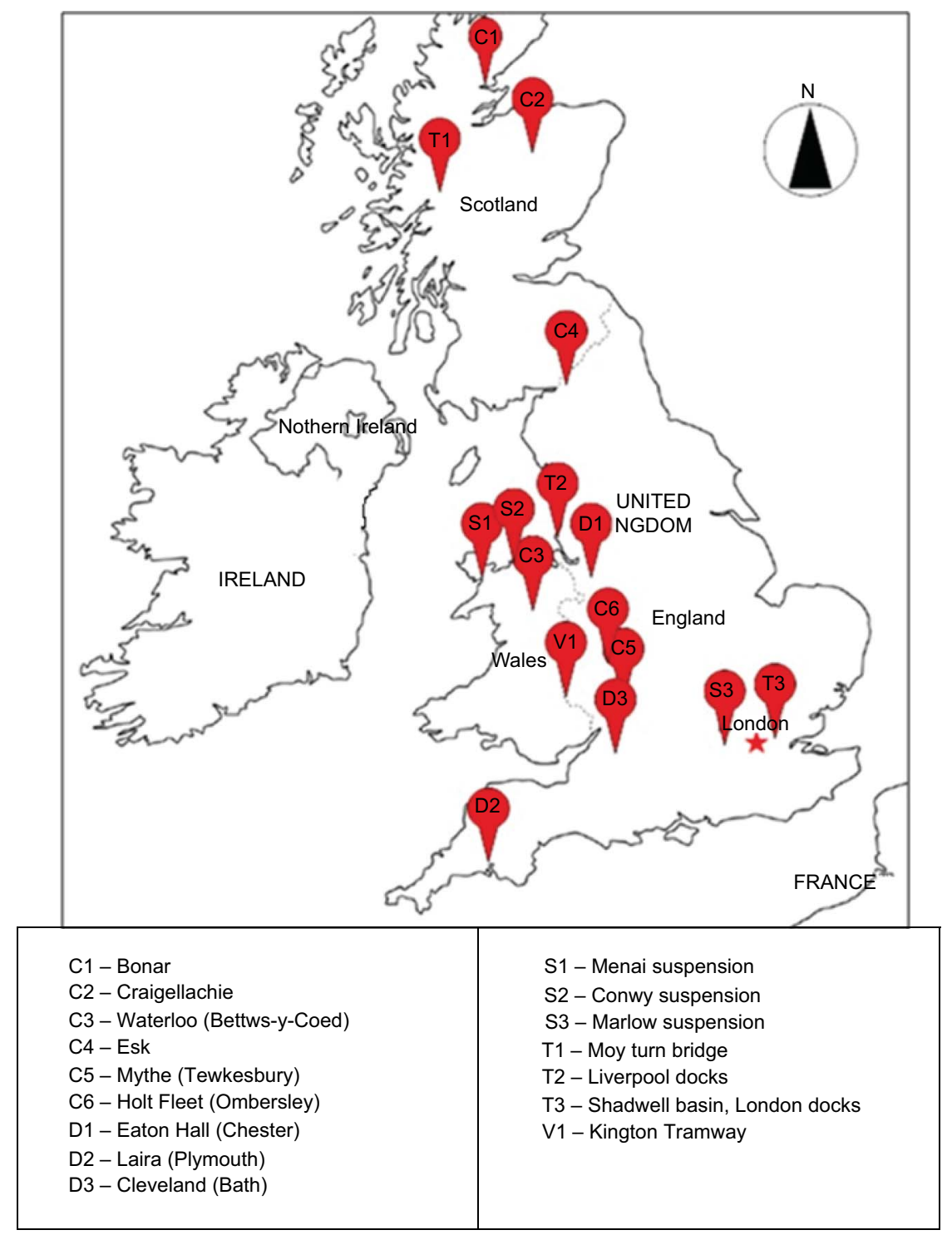

Figure 16. Outline map of location of all the bridges built by William Hazledine beyond Shropshire

When the chains came to be replaced, '...it was found advantageous to write a program for processing on an electronic computer [a novelty in 1966!], the calculation of the lengths of the eye-bar chain links, the geometry of the connector plates carrying the suspenders being somewhat complex' (Wadsworth and Waterhouse, 1967). Hazledine didn't have such luxuries as computers in the 1820 s - just experience and practical knowhow!

The huge geographical area covered by bridges from Hazledine's ironworks, and the outstanding legacy that he has provided, are illustrated in Figure 16.

\section{Dublin docks}

Around 1820 Hazledine provided the ironwork for the Custom House Docks in Dublin. Although this was not Hazledine's finest hour, his work on Dublin docks illustrates the complexities of undertaking major contracts at that time. The project also demonstrated Hazledine's close friendship with, and indebtedness to, Telford who acted as a consultant for the dock work. Hazledine's contribution was to supply the roof, columns, beams and other ironwork for the west store (Cox, 2009). Contracts were signed in October 1820, with a completion date of December 1821 (ICE, 1820-1825, T/EG 139). By December 1821 it was clear that Hazledine was well 
behind schedule, and the resident engineer, John Aird, was despatched to Shrewsbury to investigate (ICE, 1820-1825, T/EG 96). Despite a favourable report, the Admiralty Board quickly began demanding compensation from Hazledine and applied to Telford for a report. Telford produced this in March 1822, stating that 'if consulted I should have advised the Board to allow another year [for the contract]'. Telford reduced the claim to $£ 500$, going on to state that 'I have from 20 years' experience found him [Hazledine] very industrious and capable of great exertion and performing his work well.' Telford also cited in mitigation 'the excess anxiety of transporting by sea as ... evidenced by a cargo containing all the ironwork having been shipped at Chester 6 weeks ago, and not yet arrived in Dublin ...' (ICE, 1820-1825, T/EG 93). The roof was shipped in June 1822 (ICE, 1820-1825, T/EG 27), but quite what happened to some of the other ironwork is not known, for Hazledine later wrote that he had had to have some components cast again in Dublin 'at great cost' and the items cast in Shrewsbury were not used (ICE, 1820-1825, T/EG 72). The work was eventually completed in 1823 , but the dispute over the size of the penalty rumbled on. In the end Hazledine travelled to London to be interviewed by the Lords of the Treasury. They were evidently sympathetic to his problems and reduced the penalty by $£ 250$ (ICE, 1820-1825, T/EG 106, 124). After this visit to London Hazledine wrote to Telford, 'I was in hopes of seeing you in person ... I am very sorry to have given my friends so much trouble in this business, but the balance will be of essential service to me' (ICE, 1820-1825, T/EG 124) (see Appendix).

\section{Conclusion}

The fact that William Hazledine and Thomas Telford became friends at the formative stage of both their careers, and remained both friends and collaborators throughout their working lives was significant for both of them. Without Telford and his contracts through the country, Hazledine is unlikely to have had the opportunity to make an impact beyond his local area. On the other hand, Hazledine's technical expertise in a material that was initially unfamiliar to Telford must have enabled the engineer to have confidence that the novel structures he designed would actually function as he had planned. Over 200 years of history since their construction has amply demonstrated the genius of both the engineer and the manufacturer.

The paper has highlighted the outstanding quality of the iron that Hazledine made for his many structures and the rigorous proof tests he undertook to verify the properties of the metal. These results will be of great interest to engineers today working on heritage cast- and wrought-iron structures, if only to learn of the high-quality results that were possible by developing great expertise in making and using the new material; a word of caution is that not all iron manufacturers from the late eighteenth and early nineteenth centuries were as competent as Hazledine.

\section{Acknowledgement}

The author is indebted to the trustees for a Pagett Bursary at Ironbridge Institute, which supported much of this study.

\section{Appendix}

Table 5 shows William Hazledine's significant works (mill work not included). 


\section{Aqueducts}

Vyrnwy, Montgomery Canal, SJ 254197

Chirk, Ellesmere Canal, SJ 287373

Pontcysyllte, Ellesmere Canal, SJ 253409

Nantwich, Birmingham and Liverpool

Canal, SJ 641526

Stretton, Birmingham and Liverpool

Canal, SJ 871107

Small cast-iron arch bridges

Meole Brace, Shrewsbury, SJ 491107

Long Mill, Longdon-on-Tern,

Shropshire, SJ 617155

Cantlop, Shropshire, SJ 517063

Cound, Shropshire, SJ 558057

Dolforgan, Kerry, Powys, SO 144901

Large cast-iron arch bridges

Bonar Ferry, Sutherland, NH 609917

Craigellachie, Grampian, NJ 285452

'Waterloo', Bettws-y-Coed, Gwynedd, SH 799557

River Esk, Cumbria, NY 354649

Eaton Hall, near Chester, SJ 418601

Mythe, Tewkesbury, SO 889337

Laira, Plymouth, TA 044882

Cleveland, Bath, SO 753657

Holt Fleet, Ombersley, Worcs, SO 824634

Suspension bridges

Menai, Gwynedd, SH 556714

Conwy, Gwynedd, SH 785776

Marlow, Bucks, SU 851860

\section{Cast-iron turn bridges}

Göta Canal, Sweden

Moy, Highland, NN 162836

Princes and Georges Docks, Liverpool, site unknown
1797 Masonry aqueduct - later strengthened; still in use

1801 Iron base supplied and fitted by Hazledine, still in use

1805 Complete iron trough supplied and fitted by

Hazledine; in use

1830 One cast-iron arch, $30 \mathrm{ft}$ span; in use

1833 Similar to Nantwich; in use

$181155 \mathrm{ft}$ span, demolished 1933

$1812 \quad 28 \mathrm{ft}$ span, demolished 1883

$1813 \quad 31 \mathrm{ft}$ span, in place, but bypassed

$181855 \mathrm{ft}$ span, dismantled 1967, part re-erected in Telford town centre

1818 Small estate bridge, now disused

1813 One $55 \mathrm{ft}$ arch; washed away 1892

1814 Identical to Bonar; still in place, but bypassed

1816 One $105 \mathrm{ft}$ arch; remains in use after strengthening

1820 One arch of $150 \mathrm{ft}$, two of $105 \mathrm{ft}$; demolished 1911

1824 Estate bridge, one arch of $55 \mathrm{ft}$; still in use

1826 One arch of $170 \mathrm{ft}$; strengthened, still in use

1827 Five arches, total span $452 \mathrm{ft}$; demolished 1962

1827

1828 One arch of $150 \mathrm{ft}$; strengthened, still in use

1826

1832

1818

1820

'1820s'
One arch $110 \mathrm{ft}$; strengthened, still in use

$579 \mathrm{ft}$ span wrought iron chains; chains replaced with steel 1938; light traffic

$328 \mathrm{ft}$ span, same design as Menai; now pedestrian only $200 \mathrm{ft}$ span - replaced with steel 1966; light traffic

A number of turn bridges; current status unknown Over Caledonian Canal for farm traffic; still in use Replaced late nineteenth century
Thomas Dadford Thomas Telford Telford

Telford

Telford

Telford/Thomas

Stanton

Telford/Stanton

Telford/Stanton

Telford/Stanton

Hazledine

Telford

Telford

Telford

Telford

Hazledine/William Stuttle - Telford

design

Telford

JM Rendel

Henry Goodridge/

Hazledine

Telford

Telford

Telford

William Tierney

Clark

Telford

Telford

Unknown

Note: Montrose chain bridge has been attributed to Hazledine (Skempton and Chrimes (eds), 2002, William Hazledine). It was, however, designed and built by Captain Samuel Brown (Skempton and Chrimes (eds), 2002, Samuel Brown)

Table 5. William Hazledine's significant works (mill work not included) (Pattison, 2012; Skempton and Chrimes, 2002).

(continued on next page) 


\begin{tabular}{|c|c|c|c|}
\hline Structure and location & Date & Notes & Engineer \\
\hline $\begin{array}{l}\text { Shadwell entrance, Eastern Dock, } \\
\text { London, TQ } 355805\end{array}$ & 1831 & $\begin{array}{l}46 \mathrm{ft} \text { span; replaced late nineteenth century by bascule } \\
\text { bridge }\end{array}$ & Telford \\
\hline \multicolumn{4}{|l|}{ Miscellaneous works } \\
\hline Land drainage, Deytheur, Powys & 1792 & Working for William Pulteney & Hazledine \\
\hline $\begin{array}{l}\text { Ironwork for Ditherington Flax Mill, } \\
\text { Shrewsbury, SJ } 498128\end{array}$ & 1797 & $\begin{array}{l}\text { First fully iron-framed building in the world; being } \\
\text { restored }\end{array}$ & Charles Bage \\
\hline Welshpool Town Hall & 1804 & Enlarged 1836, demolished 1873 & $\begin{array}{l}\text { Hazledine/ } \\
\text { Simpson }\end{array}$ \\
\hline $\begin{array}{l}\text { River Severn towpath, Coalbrookdale } \\
\text { to Shrewsbury }\end{array}$ & 1809 & $\begin{array}{l}6 \mathrm{ft} \text { wide horse towing path, with unknown number } \\
\text { of small bridges; nothing survives }\end{array}$ & Hazledine \\
\hline Caledonian Canal & From 1810 & 14 pairs of lock gates for western half of canal & Telford \\
\hline Göta Canal, Sweden & 1818 & One pair of lock gates & Telford \\
\hline $\begin{array}{l}\text { Kington Tramroad, Herefordshire, } \\
\text { terminus SO } 314491\end{array}$ & 1820 & 8 mile tramroad from Kington to Eardisley; little survives & Hazledine \\
\hline St John's Market, Liverpool & 1822 & 116 interior cast-iron pillars; demolished 1964 & John Foster junior \\
\hline $\begin{array}{l}\text { Dublin Custom House Docks west } \\
\text { store - roof, beams etc. }\end{array}$ & 1823 & Redeveloped late 1980s & John Rennie \\
\hline Lock gates for Newport Docks & 1840 & History not known & Not known \\
\hline
\end{tabular}

Table 5. Continued

\section{REFERENCES}

Alan Baxter and Associates (2006) Ditherington Flax Mill, Shrewsbury, Structural Engineering Appraisal - Main Report. Archive Report for English Heritage.

Anon (1628ff) Shropshire Archives (SA) Waters Upton Parish Records, S9/746SA. SA, Shrewsbury, UK.

Anon (1763) SA - Shawbury Parish records, fiche P241/A/53. SA, Shrewsbury, UK.

Anon (1788) SA - Salt collection, SA D3651/B/9/5/8/16. SA, Shrewsbury, UK.

Anon (1790) SA - Salt collection, SA D3651/D/5/214. SA, Shrewsbury, UK.

Anon (1791) SA - Salt collection, SA D3651/D/14/113. SA, Shrewsbury, UK.

Anon (1792a) SA - Salt collection, SA D3651/D/14/120. SA, Shrewsbury, UK.

Anon (1792b) SA - Salt collection, SA D3651/D/5/228. SA, Shrewsbury, UK.

Anon (1793a) SA - Salt collection, SA D3651/D/5/246. SA, Shrewsbury, UK.

Anon (1793b) General Committee minutes of the Ellesmere Canal Co., RAIL 827/5. The National Archives, London, UK.

Anon (1799) General Committee minutes of the Ellesmere Canal Co., RAIL 827/2. The National Archives, London, UK.

Anon (1802) General Committee minutes of the Ellesmere Canal Co., RAIL 827/2. The National Archives, London, UK.
Anon (1804) SA - Bridgwater Papers 212/Box 366. SA, Shrewsbury, UK.

Anon (1805) Extracts from General Committee Orders of the Ellesmere Canal Co., RAIL 827/7. The National Archives, London, UK.

Anon (1806) SA - Oration to mark the opening of Pontcysyllte aqueduct 26.11.1805, published by J\&W Eddowes, 1806, SA WD25.7. SA, Shrewsbury, UK.

Anon (1836) Shropshire Archives PH/S/13/M/11. SA, Shrewsbury, UK.

Anon (1840) Obituary of William Hazledine. Shrewsbury Chronicle, 30 October 1840.

Blackwall A (1985) Historic Bridges of Shropshire. Shropshire Libraries and Highways and Transport Department, Shropshire County Council, Shrewsbury, UK.

Burton A (1999) Thomas Telford. Aurum, London, UK.

Burton A (2007) Thomas Telford and the Göta Canal. Journal of the Railway and Canal Historical Society 34(3): 544 547.

Cox R (2009) Telford in Ireland: work, opinions and influence. Engineering History and Heritage 162(1): 51-60.

Day W (2007) Telford's Menai and Conwy suspension bridges, Wales. Proceedings of the Institution of Civil Engineering Civil Engineering 160(5): 26-30.

Dodds N, Locke L and Welsford R (1995) Recent strengthening work on Cleveland Bridge, Bath. The Structural Engineer 73(5): 69-75.

Elliott DJ (1979) Shropshire Clock and Watchmakers. Phillimore, Chichester, UK, pp. 79-80. 
Engineering Timelines (2013a) Moy Bridge. See http://www. engineering-timelines.com/scripts/engineeringItem. asp?id=319 (accessed 29/11/2013).

Engineering Timelines (2013b) Thomas Telford. See http:// www.engineering-timelines.com/who/Telford_T/ telfordThomas7.asp (accessed 01/11/2013).

Engineering Timelines (2014) Hazledine \& Co, Bridgnorth. See http://www.engineering-timelines.com/scripts/ engineeringItem.asp?id=1193 (accessed 15/05/2014).

Gibb SA (1935) The Story of Telford. Alexander Maclehose \& Co., London, UK.

Greenwood C (1827) Greenwood's Map of the County of Salop. Greenwood and Co., London, UK.

Hadfield C (1969) Telford, Jessop and Pontcysyllte. Journal of the Railway and Canal Historical Society 15(4): 69-74.

Hadfield C (1993) Thomas Telford's Temptation. M\&M Baldwin, Cleobury Mortimer, UK.

Hill MC (1959) Iron and steel bridges in Shropshire. Transaction of Shropshire Archaeological Society LVI: 106.

Hughes S (2004) Hazeldine [sic], William (1763-1840). Oxford Dictionary of National Biography. Oxford University Press, Oxford, UK. See http://www.oxforddnb.com/view/article/ 12802 (accessed 04/02/2014).

Hulbert C (1837) The History and Description of the County of Salop. Charles Hulbert, Shrewsbury, UK, p. 308, footnote.

ICE (1818) Telford correspondence. Pontcysyllte Aqueduct 1818 - T/EG 306. ICE, London, UK.

ICE (1819) Telford correspondence. Göta Canal - 1819 - T/GC 208. ICE, London, UK.

ICE (1820-1825) Telford correspondence. Dublin docks 1820-25 - T/EG 27, 72, 93, 96, 106, 124, 139. ICE, London, UK.

ICE (1825) Menai Bridge - 1825 - T/EG 125. ICE, London, UK.

Ironbridge Gorge Museum Trust (IGMT) (1796) Telford correspondence. Letter to Matthew Davidson - 19 February 1796 -1981.3587. IGMT, Telford, UK.

Lowson WW (1967a) The reconstruction of the Craigellachie Bridge. The Structural Engineer 45: 23-29.

Lowson WW (1967b) The reconstruction of the Craigellachie Bridge (Discussion). The Structural Engineer 45(8): 287289.

Mackenzie W (1838) Account of the bridge over the Severn, near the town of Tewkesbury, in the County of Gloucester, designed by Thomas Telford, and erected under his superintendence (including plates). Transactions of the Institution of Civil Engineers 2(1838): 1-14.

Measuringworth (2013) http://www.measuringworth.com/ index.php (accessed 27/11/2013).

Minshull T (1803) The Shrewsbury Visitor's Pocket Companion and Salopian Guide.

Pattison A (2007) Thomas Telford's Shrewsbury team:
Thomas Telford, William Hazledine and John Simpson. Journal of the Railway and Canal Historical Society 35(9): 664-675.

Pattison A (2012) William Hazledine, Shropshire Ironmaster and Millwright: A Reconstruction of his Life, and his Contribution to the Development of Engineering, 1780-1840. MPhil thesis, University of Birmingham, UK. See http:// etheses.bham.ac.uk/3358/1/Pattison12MPhil.pdf (accessed 14/10/2013). This reference is the source for otherwise unreferenced material in this article.

Paxton RA (1980) Menai Bridge 1818-26 - evolution of design. In Thomas Telford, Engineer (Penfold A (ed.)). Thomas Telford, London, UK, pp. 84-116.

Paxton RA (2007) Thomas Telford's cast-iron bridges. Civil Engineering 160 (May): 12-19.

Paxton RA and Shipway J (2007) Civil Engineering Heritage, Scottish Highlands and Islands. RCAHMS.

Pontcysyllte Aqueduct computer animation (2013) See http:// vimeo.com/2267361 (accessed 01/11/2013).

Provis W (1828) An Historical and Descriptive Account of the Suspension Bridge Constructed over the Menai Straits in North Wales. Alexander Maclehose, London, UK.

Rolt LTC (1979) Thomas Telford. Pelican, London, UK.

Royal Commission for the Ancient and Historic Monuments of Scotland (2011) See http://www.scran.ac.uk/database/ record.php?usi000-299-994-129-C\&searchdbscran\& scache5dzp64msoe (accessed 3/6/2011).

Scotsites eBooks (2011) See http://www.scotsites.co.uk/ebooks/ lifeoftelfordchapter14.htm (accessed 01/03/2011).

Shrewsbury Local History (2013) See http://www. shrewsburylocalhistory.org.uk/stanton.htm (accessed 29/11/2013).

Shropshire Notes and Queries (1901) Shrewsbury Chronicle, 8, 15, 22 and 29 November, 6 December.

Skempton A (1981) Engineering in the Port of London, 1808-1834. Transactions of Newcomen Society 53: 73-96.

Skempton A and Chrimes M (eds) (2002) A Biographical Dictionary of Civil Engineers in Great Britain and Ireland. Thomas Telford, London, UK, vol. 1, pp. 311-313.

Skempton A and Johnson H (1962) The first iron frames. Architectural Review (March): 175-186.

Taylor A, Plant C and Dickerson J (2009) Wellington Street Swing Bridge, Hull, UK. Engineering History and Heritage 162(2): 67-79.

Telford T (1798) On Mills - A Report for the Board of Agriculture. ICE, London, UK.

Telford T and Burne E (1936) On mills. Transactions of the Newcomen Society 17: 205-214.

Telford T and Rickman J (1838) Life of Telford. Hansard, London, UK, pp. 62-64. 
Trinder B (1992) Ditherington Flax Mill, Shrewsbury - a re-evaluation. Textile History 23(2): 189-223.

Wadsworth H and Waterhouse A (1967) Modern techniques and problems in the restoration of Marlow suspension bridge. Proceedings of Institution of Civil Engineers 37(2): 297-316.

Welch C (1966) The Iron Bridge at Plymouth. Transactions of the Devon Association 98: 370-385.

\section{WHAT DO YOU THINK?}

To discuss this paper, please email up to 500 words to the editor at journals@ice.org.uk. Your contribution will be forwarded to the author(s) for a reply and, if considered appropriate by the editorial panel, will be published as discussion in a future issue of the journal.

Proceedings journals rely entirely on contributions sent in by civil engineering professionals, academics and students. Papers should be 2000-5000 words long (briefing papers should be 1000-2000 words long), with adequate illustrations and references. You can submit your paper online via www.icevirtuallibrary.com/content/journals, where you will also find detailed author guidelines. 